NBER WORKING PAPER SERIES

\title{
POLICY IMPLICATIONS OF NON-LINEAR EFFECTS OF TAX CHANGES ON OUTPUT
}

\author{
Samara R. Gunter \\ Daniel Riera-Crichton \\ Carlos A. Vegh \\ Guillermo Vuletin \\ Working Paper 28646 \\ http://www.nber.org/papers/w28646 \\ NATIONAL BUREAU OF ECONOMIC RESEARCH \\ 1050 Massachusetts Avenue \\ Cambridge, MA 02134 \\ April 2021
}

We would like to thank seminar participants at the International Monetary Fund, Inter-American Development Bank, World Bank, Federal Reserve Board, European Stability Mechanism, Central Bank of Argentina, Central Bank of Chile, Central Bank of Spain, UN Economic Commission for Latin America and the Caribbean, George Washington University, Johns Hopkins University, Williams College, Davidson College, Universidad Nacional de La Plata, Sao Paulo School of Economics-Getulio Vargas Foundation, Escola Superior d'Administració i Direcció d'Empreses (ESADE), Institute of Education and Research (INSPER), International Macro Workshop-RIDGE, Latin American and Caribbean Economic Association (LACEA), Annual Symposium of the Spanish Economic Association, and XLIV Meeting of the Network of Central Banks and Finance Ministries-IDB for many helpful comments and suggestions. We would also like to thank Alberto Alesina, Silvia Albrizio, Leopoldo Avellan, Frank Bohn, Fernando Broner, Eduardo Cavallo, Javier GarciaCicco, Aitor Erce, Davide Furceri, Vitor Gaspar, Alejandro Izquierdo, Herman Kamil, Graciela Kaminsky, Aart Kraay, Gerardo Licandro, Alessandro Notarpietro, Peter Montiel, Eduardo Moron, Ilan Noy, Pablo Ottonello, Peter Pedroni, Javier Perez, Roberto Ramos, David Robinson, Diego Saravia, Olena Staveley-O'Carroll, Jay Shambaugh, Hamilton Taveras, Teresa TerMinassian, and Martin Uribe for helpful discussions, and José Andrée Camarena Fonseca, Diego Friedheim, Pablo Hernando-Kaminsky, and Luis Morano for excellent research assistance. The views expressed herein are those of the authors and do not necessarily reflect the views of the National Bureau of Economic Research.

NBER working papers are circulated for discussion and comment purposes. They have not been peer-reviewed or been subject to the review by the NBER Board of Directors that accompanies official NBER publications.

(C) 2021 by Samara R. Gunter, Daniel Riera-Crichton, Carlos A. Vegh, and Guillermo Vuletin. All rights reserved. Short sections of text, not to exceed two paragraphs, may be quoted without explicit permission provided that full credit, including $\odot$ notice, is given to the source. 
Policy Implications of Non-Linear Effects of Tax Changes on Output

Samara R. Gunter, Daniel Riera-Crichton, Carlos A. Vegh, and Guillermo Vuletin

NBER Working Paper No. 28646

April 2021

JEL No. E32,E62,H20

\begin{abstract}
In an earlier paper, titled "Non-linear effects of tax changes on output: The role of the initial level of taxation," we estimated tax multipliers using (i) a novel dataset on value-added taxes for 51 countries (21 industrial and 30 developing) for the period 1970-2014, and (ii) the so-called narrative approach developed by Romer and Romer (2010) to properly identify exogenous tax changes. The main finding is that, in line with existing theoretical distortionary and disincentivebased arguments, the effect of tax changes on output is highly non-linear. The tax multiplier is essentially zero under relatively low/moderate initial tax rate levels and more negative as the initial tax rate and the size of the change in the tax rate increase. This companion paper first shows that these findings have important policy implications, given that the initial level of taxes varies greatly across countries and thus so will the potential output effect of changing tax rates. The paper then turns to some specific policy applications. It focuses on the relevance of the arguments for revenue mobilization in countries with low levels of provision of public goods and social and infrastructure gaps, as well as in commodity-dependent countries. The paper then considers some practical implications for the standard debt sustainability analysis. Lastly, it evaluates the implications of the findings for the Laffer curve.

Samara R. Gunter

Colby College

5230 Mayflower Hill

Waterville, ME 04901

srgunter@colby.edu

Daniel Riera-Crichton

The World Bank

1818 H St NW

Washington, DC 20433

drieracr@bates.edu

Carlos A. Vegh

School of Advanced International Studies (SAIS)

Johns Hopkins University

1717 Massachusetts Avenue, NW

Washington, DC 20036

and NBER

cvegh1@jhu.edu

Guillermo Vuletin

The World Bank

1818 H Street NW

Washington, DC 20433

gvuletin@worldbank.org
\end{abstract}




\section{Introduction}

In Gunter et al. (2021), we estimate tax multipliers using (i) a novel dataset on value-added taxes for 51 countries (21 industrial and 30 developing) for the period 1970-2014 and (ii) the narrative approach developed by Romer and Romer (2010) to properly identify exogenous tax changes. The main empirical finding is that there are strong non-linear effects of taxation on output. In particular, and in line with existing theoretical distortionary and disincentivebased arguments, we show that the effect of tax changes on output is essentially zero for

relatively low initial tax rate levels or small tax changes and becomes increasingly negative under higher initial tax rates or larger tax changes. The reason is that the distortion imposed by taxation on economic activity is directly, and non-linearly, related to both the initial level of the tax rate and the size of the tax change.

Figure 1 reproduces a key result from our 2021 paper. This figure reports the estimated tax multiplier after two years, evaluated at alternative initial tax rate levels and different sizes of the tax change. We can see that the most negative multipliers occur for the highest values in both axes. In other words, while the fall in output associated with increasing revenues by $\$ 1$ tends to be zero for low levels of the initial tax rate and small tax hikes, this cost becomes much larger as the initial tax rate and the size of the tax hike increase. Hence, the evidence shows that the output effect of tax changes is, indeed, highly non-linear.

\section{INSERT FIGURE 1 HERE}

These findings have important policy implications given that the initial level of taxes varies greatly across countries and thus so will the potential output effect of changing tax rates. Figure 2 shows that, given countries' current VAT rate, the tax multiplier could be statistically zero (dark blue color), or moderate to high (yellow, orange, and red colors). For example, a 1.5 percentage-points increase in the VAT rate would essentially not affect GDP in countries with low tax rates such as Angola, Costa Rica, Guatemala, Ecuador, Nigeria, and Paraguay. In contrast, the same tax increase (decrease) would cause output to fall (increase) in economies with relatively high VAT rates, including some emerging markets like Argentina and Uruguay and, especially, many industrial European countries. For example, according to our estimates, the 1 percentage-point increase that took place in Greece in June 2016 (when the VAT rate changed from 23 to 24 percent) should, in and on itself, have reduced GDP by about 1.75 percent by June 2018. In contrast, the 2 percentage-point increase that took place in Ecuador 
in January 2000 (when the VAT changed from 10 to 12 percent) should not, in and on itself, have affected GDP.

\section{INSERT FIGURE 2 HERE}

This companion paper discusses some relevant policy applications that result from the non-linear effects of tax changes on output. We first focus on the relevance of our arguments for revenue mobilization in countries with low levels of provision of public goods and social and infrastructure gaps (Section 2) as well as in commodity-dependent countries (Section 3). Section 4 then explores some practical implications for debt sustainability analysis (DSA). Section 5 analyzes the non-linear implications in terms of the Laffer curve. Finally, Section 6 offers some concluding remarks.

\section{Policy implications I: On the relationship between the size of the government and economic development}

The role and the size of the government in an economy have been studied from different perspectives in the literature. Some of the main determinants of government spending as a proportion of GDP include trade openness (Rodrik, 1998), country size (Alesina and Wacziarg, 1998), degree of economic development (Wagner, 1883, 1893; Easterly and Rebelo, 1993), political organization (Persson and Tabellini, 1999; Milesi-Ferretti, Perotti, and Rostagno, 2002), and business cycle volatility (Fatas and Mihov, 2001).

Within this broad set of theories, one that has received considerable attention focuses on the relationship between the size of the government and the degree of economic development. In fact, one of the best-established empirical regularities in public finance is the existence of a positive relationship between the size of government spending (relative to GDP) and real GDP per capita. This so-called Wagner's Law, also known as the law of increasing state activities, is named after the German economist Adolph Wagner's empirical analysis of Western Europe at the end of the 19th century. Wagner $(1883,1893)$ pointed out that, as national income rises, public spending tends to increase, both at the extensive margin (i.e., new activities are undertaken) and intensive margin (i.e., existing activities are performed on a larger scale). Specifically, Wagner argued that the public sector would take over and expand administrative, regulatory, and protective activities previously performed by the private sector because, as nations develop, they face increased complexity in terms of legal and ad- 
ministrative frameworks. Wagner also predicted the expansion of public expenditures related to culture and welfare based on the presumption that as income rises, citizens will increase the demand for services, such as education, public health, old age pension, and other social protection programs. In fact, these types of goods and services are viewed as luxury goods (i.e., the income elasticity of demand exceeds unity) and have, in principle, more characteristics of public goods than private goods, in which case public provision seems to be the norm. Finally, Wagner was of the view that government intervention would be required to manage and finance natural monopolies and ensure the smooth operation of market forces. While not uncontested, these arguments were later refined by, among others, Peacock and Wiseman (1967), Musgrave (1969), and Bird (1971).

Figure 3 shows that, as predicted by Wagner's law and a large, and more recent, body of empirical evidence, there is indeed a very strong association between GDP per capita and the size of government spending (relative to GDP). ${ }^{1}$ Based on this framework, countries above (below) the fitted line are countries with a size of government spending larger (smaller) than that of a typical country with the same level of income per capita. ${ }^{2}$ For example, Honduras a lower-middle-income country, based on the World Bank income classification, with a GDP per capita of $\$ 4,785$ - has a ratio of public spending to GDP of 23 percent, while Jamaica's an upper-middle-income country with a GDP per capita of $\$ 8,528$ - is 27 percent. However, Costa Rica - an upper-middle-income country with a GDP per capita of $\$ 14,471$ (i.e., a per capita income 3 times as high and 70 percent larger than that of Honduras and Jamaica, respectively) - has a ratio of public spending to GDP of just 18 percent.

\section{INSERT FIGURE 3 HERE}

Interestingly, defining "excess" spending as the ratio G/GDP minus the predicted ratio G/GDP from the fitted line in Figure 3, it follows, from individual country examples in Figure 3 and more systematic evidence from Figure 4, that countries with positive excess spending (like Honduras, Jamaica, Argentina, and Greece) tend to have higher VAT rates than those

\footnotetext{
${ }^{1}$ Most of the recent empirical evidence regarding the existence of Wagner's law is based on country-specific analyses as opposed to cross-sectional analyses (like the one shown in Figure 3). While, strictly speaking, a cross-sectional analysis is technically less accurate (as it does not control for other country determinants that may be constant over time), this more global cross-section analytical framework should allow us to draw some relevant policy insights in a more transparent way.

${ }^{2}$ For comparison purposes, GDP per capita is PPP-based. Figures are in constant 2011 PPP dollars.
} 
with negative excess spending (like Guatemala, Costa Rica, New Zealand, and Australia).

\section{INSERT FIGURE 4 HERE}

This evidence suggests that countries such as Guatemala, with a low level of provision of public goods for its degree of development, may reach a more typical level of provision of public goods by collecting more revenues from increases in the VAT rate with little effect on economic activity. Note that this analysis is quite conservative regarding the positive effect of these fiscal changes since it does not include the potential output effect of higher government spending (associated with larger fiscal revenues). In fact, in the 2016 Article IV Consultation for Guatemala, the IMF argued that

[w] hile the first-best option is to quickly mobilize revenue to cover the originally planned budget spending in 2016, a temporary relaxation of the overall deficit (to its historical average of 2 percent of GDP) could be justified to prevent further cuts in social and capital spending in the event of revenue shortfalls. The acute problem of extreme poverty and malnutrition as well as the dire infrastructure and security needs could warrant maintaining a deficit at 2 percent of GDP, or even modestly higher, over the medium term to allow the time needed for revenue mobilization ...This would not jeopardize fiscal sustainability (Annex III) and be consistent with current implementation capacity [Moreover,] tax policy measures are also needed... Reform of tax and customs administration is a key priority, both to raise revenue and reduce corruption.

This view about the importance of revenue mobilization in countries with low levels of provision of public goods and social and infrastructure gaps is, indeed, in line with the evidence presented in Figures 3 and 4 . In a similar vein, and mainly due to the need to reduce the fiscal deficit, Costa Rica's fiscal authorities sent to Congress in 2016 a draft law to increase the VAT rate by one percentage point in 2016 (i.e., from 13 to 14 percent) and another one in 2017 (from 14 to 15 percent). 


\section{Policy implications II: On revenue mobilization in commodity- dependent countries}

Since the fall in commodity prices in 2014, most commodity-rich countries (especially those whose fiscal revenue structure depends "excessively" upon commodity revenues) have been facing a growing fiscal challenge as the price fall has increasingly been perceived as more permanent than anticipated. Indeed, Figure 5 shows, for a sample of 55 countries for which commodity revenue data were available, that the share of commodity revenues (as percentage of total revenues) tracks very well that of commodity prices. ${ }^{3}$ Since commodity prices are expected to remain low in the years to come, so will commodity revenues. This, in turn, shows the serious challenge faced by commodity-rich countries and particularly by those with high commodity revenue dependency.

\section{INSERT FIGURE 5 HERE}

Figure 6 shows the association between the economy's dependency on commodities (proxied by the commodity GDP as a percentage of total GDP) and the commodity revenue dependency (proxied by commodity revenues as a percentage of total revenues). Not surprisingly, the fitted line shows that the higher is commodity GDP, the larger is the share of commodity revenues in total revenues. ${ }^{4}$ For example, in a country like Kuwait, where oil production represents about 60 percent of total GDP, oil revenues constitute about 90 percent of total revenues. In contrast, in the Philippines, oil production represents less than 1 percent in both GDP and fiscal revenues. One can view countries above the fitted line as countries whose fiscal revenue structure depends "excessively" upon commodity revenues relative to a typical country with the same level of economic dependency on commodities. The opposite is true for countries below the fitted line. For example, while in Papua New Guinea commodity

\footnotetext{
${ }^{3}$ The commodity coverage includes mining and/or hydrocarbons commodities. The list of countries and commodity coverage comprises the following countries. For both mining and/or hydrocarbons commodities: Australia, Bolivia, Brazil, Canada, Colombia, DRC, Indonesia, Mauritania, Papua New Guinea, and Vietnam. For hydrocarbons commodities: Algeria, Angola, Azerbaijan, Bahrain, Brunei, Cameroon, Chad, Congo Republic, Ecuador, Equatorial Guinea, Iran, Iraq, Ivory Coast, Kazakhstan, Kuwait, Libya, Malaysia, Mexico, Myanmar, Namibia, Niger, Nigeria, Norway, Oman, Philippines, Qatar, Russia, Saudi Arabia, Sudan, Syria, Timor-Leste, Trinidad and Tobago, United Arab Emirates, United Kingdom, Uzbekistan, Venezuela, and Yemen. For mining commodities: Botswana, Chile, Ghana, Guinea, Guyana, Kyrgyz Republic, Lesotho, Mongolia, Peru, Sierra Leone, Tanzania, and Zambia.

${ }^{4}$ Unlike Figure 3, Figure 6 suggests that a non-linear estimation would not increase the predictive power relative to the linear estimation.
} 
production represents about 32 percent of GDP and revenue dependency is about 34 percent, in Nigeria commodity production represents about 18 percent of GDP (i.e., almost half of that of Papua New Guinea) and revenue dependency is about 77 percent (i.e., more than twice as that observed in Papua New Guinea).

\section{INSERT FIGURE 6 HERE}

Interestingly, defining "excess" commodity revenue dependency as commodity revenue (as percentage of GDP) minus the predicted commodity revenue (as percentage of GDP) from the fitted line of Figure 6, it follows, from individual country examples in Figure 6 and more systematic evidence from Figure 7, that countries with "excess" commodity revenue dependency (like Malaysia, Yemen, and Nigeria) tend to have lower VAT rates (or no VAT at all, as in the cases of Bahrain, Brunei, and Iraq) than those with negative "excess" commodity revenue dependency (like Chile, Papua New Guinea, Trinidad and Tobago, and Republic of Congo).

\section{INSERT FIGURE 7 HERE}

This evidence suggests that countries, such as Nigeria, with "excessive" dependency on commodity revenues could quickly mobilize revenues from non-commodity related activities by increasing their VAT rates with relatively little effect on economic activity. This evidence is in line with the IMF 2016 Nigeria's Article IV Consultation, which "urged a gradual increase in the VAT rate, further improvements in revenue administration, and a broadening of the tax base." It should be noted that Nigeria is one of Africa's largest economies and has one of the lowest VAT rates in the world at 5 percent. In particular, Nigeria's VAT rate is much lower than that of other members of the Economic Community of West African States (ECOWAS). The average VAT rate in the ECOWAS (excluding Nigeria) is 16.5 percent, with rates between 10 and 20 percent. In fact, several proposals have been submitted to the Nigerian Congress to deal with the new normal of low oil prices, with new VAT rate proposals ranging from 7.5 to 10 percent. This view about the importance of revenue mobilization in countries whose fiscal revenue structure depends "excessively" on commodities is in line with the evidence presented in Figures 6 and 7. Indeed, several commodity-dependent economies including Nigeria, Bahrain, Kuwait, Oman, Qatar, Saudi Arabia, and United Arab Emirates (with no VAT or GST taxes) are planning to increase/implement a VAT rate. 


\section{Policy implications III: Debt sustainability analysis (DSA)}

This section explores some practical implications of the non-linear effect of tax changes on output for DSA. The most basic equation that characterizes the evolution of public debt dynamics at a horizon $h$ in DSA is given $b^{5}$

$$
d_{t+h}=\frac{1+\rho}{1+\theta_{t+h}} d_{t+h \square 1} \square\left(r_{t+h} \square g_{t+h}\right),
$$

where $d, r$, and $g$ denote public debt, revenue, and primary spending, respectively, expressed as a percentage of GDP, and $\rho$ is the real interest rate paid on public debt, typically assumed to be constant. Notice that $\theta$, the growth rate of output, is assumed to be exogenous. While $\theta$ is sometimes allowed to change over time (to take into account the debt implications of different growth paths), such a path is set exogenously and does not capture the endogenous response to, for example, a change in tax policy.

Given our findings regarding the non-linear response of output to tax changes, equation (1) should, ideally, internalize the endogenous response of output. Naturally, the same would be true of any other fiscal shock such as, for example, an increase or decrease in government spending. While the DSA could, in principle, also endogenize the response to any other type of shock, these endogeneity considerations seem more obvious when dealing with variables that enter directly equation (1). To analyze the effects of tax rate changes on output in the context of the DSA, we will rely on a simple, back-of-the-envelope type of analysis that enriches equation (1) by including the effect of tax changes not only on revenue collection (i.e., $r$ ), but also on output growth (i.e., $\theta$ ).

To characterize the effect of changes in tax rates in a simple way, we assume that

$$
R_{t}=\text { tax }_{\text {rate }} \times Y_{t}
$$

where $R$ and $Y$ are revenues and output, respectively. Moreover, we will assume that the growth rate at horizon $h$ depends on the change in tax rate at $h=0$. Specifically,

$$
\theta_{t+h}=\bar{\theta}+\frac{\partial \theta_{t+h}}{\partial\left({\text { tax } \left.\text { rate }_{t}\right)}\right.}
$$

\footnotetext{
${ }^{5}$ This basic approach does not take into account the currency of denomination of debt (e.g., Diaz-Alvarado, Izquierdo, and Panizza, 2004) or the uncertainty of the debt to GDP ratio by exploiting the variance and covariance among debt determinants (e.g., Arizala, Castro, Cavallo, and Powell, 2008).
} 
where $\bar{\theta}$ is an exogenous source of change in growth and the second term on the right-hand side of (3) captures the effect on economic growth at horizon $h$ of the change in the tax rate $h$ periods before. For example, when evaluating $\theta_{t+h}$ at $h=0$, one would be endogenizing the impact effect of a tax change on economic growth.

We will now resort to equations (1)-(3) and use a set of initial conditions for the variables involved to evaluate the effect of alternative approaches to DSA. Specifically, we will assume an initial stock of public debt of 50 percent of GDP, an exogenous growth rate of 2 percent (i.e., $\bar{\theta}=0.02$ ), a real interest rate of 3 percent, and a primary deficit of 2 percent. When evaluating the effects of tax changes on growth and debt-to-GDP ratio, we will focus on the effects, after 2 years, of an increase in the VAT rate of 1.5 percentage points (as in Figure 2).

Based on equation (1), Figure 8 shows, as a benchmark, that if there were no change in the VAT rate, the debt-to-GDP ratio would increase by 5 percentage points (i.e., from 50 to 55 percent) after 2 years. Naturally, in this first benchmark scenario, there would be no change in output. In the second scenario, we evaluate the effects of a 1.5 percentage-points tax hike on the debt-to-GDP ratio, without considering its effect on economic activity (the typical assumption in DSA). Given equation (2), this would imply an increase in revenues (expressed as a percentage of GDP) of 1.5 percent and, as a result, a reduction of 1.5 percent in the 2 percent primary deficit (i.e., the new post-tax hike primary deficit equals 0.5 percent). Such a reduction in the primary fiscal deficit lowers the increase in debt/GDP by 3 percentage points. In other words, the debt-to-GDP ratio increases from 50 to 52 percent (under the tax hike scenario) compared to 55 percent (under the no tax change scenario).

In the third scenario, economic activity is allowed to be affected by the tax hike in a linear way (i.e., according to conventional linear estimation strategies). Based on Gunter et al's (2021) estimations, output falls by a total of 0.9 percent after 2 years. This fall in economic activity increases the debt-to-GDP ratio which, in turn, partially offsets the positive effect on debt reduction of the fall in the primary fiscal deficit. Specifically, as indicated in Figure 8, the debt-to-GDP ratio increases by 2.4 percentage points in this case, compared to 2.0 in Scenario 2. But this begs the question: is this the proper way of endogenizing the role of tax changes on output in the DSA, given the non-linear effect of tax changes on output? Certainly not. To illustrate this, scenario 4 in Figure 8 compares two cases depending on the initial VAT rate: (i) the initial VAT rate is set at a low level (12 percent) and (ii) the initial VAT rate is set at a high level (24 percent). The difference between the two cases is striking. When the initial VAT rate is low, the growth effect is virtually zero (i.e., output falls after two 
years by just 0.1 percent). Hence, the debt-to-GDP ratio increases by 2 percentage points in this case, the same as in scenario 2. In contrast, when the initial VAT rate is high, output falls after two years by 2.8 percent. This drop in output largely offsets the positive effect in debt reduction of the fall in the primary fiscal deficit. Specifically, the rise of 1.5 percentage points in the VAT rate (from 24 to 25.5 percent) reduces the debt-to-GDP ratio by less than 2 percentage points compared to the case of "no change in VAT" (scenario 1).

\section{INSERT FIGURE 8 HERE}

These back-of-the-envelope calculations clearly suggest that endogenizing the effect of tax changes on output may have important implications for debt sustainability, particularly when the effect on output is non-linear.

\section{Policy implications IV: Implications for the Laffer curve}

The Laffer curve is a theory developed by supply-side economist Arthur Laffer. His main point is that the relationship between tax rates and tax revenues is non-linear and that the size of the tax base is affected by the response of economic agents, depending on the level of the initial tax rate. In line with our non-linear arguments, and a very large tradition in public finance that builds on the role of distortionary arguments, Laffer argued that when tax rates are "low enough", economic activity is not much distorted to begin with and that, in such a context, higher tax rates should be associated with larger tax revenues. Why? Because the size of the tax base does not decrease (increase) much in response to an increase (decrease) in tax rates. In contrast, when tax rates are "high enough" (which, in this supply-side type of arguments, is a proxy for high levels of distortion), further increases (decreases) in the tax rate could actually decrease (increase) revenues. This sort of counterintuitive association between tax rates and revenues reflects, based on supply-side arguments, the large response of economic agents to high initial levels of distortion.

Relying on our non-linear findings, Figure 9 illustrates that, indeed, this seems to be the case for the VAT. Considering, as in Figures 2 and 8, an increase in the VAT of 1.5 percentagepoints, the solid red line shows the corresponding increase in revenues as a percentage of GDP for different initial values of the VAT rate.

INSERT FIGURE 9 HERE 
For sufficiently low initial levels of the VAT rate, the increase in revenues (as a percentage of GDP) is around 1.5 percentage points (reflecting the fact that the tax base does not respond much). In contrast, the increase in revenues falls with higher initial levels of the VAT rate. In fact, for VAT rates higher than 32 percent, an increase in the VAT rate would actually decrease revenues as the response of the tax base more than offsets the direct effect of the tax rate change.

Figure 9 also shows the number of countries that, as of November 2017, have different VAT rates as well as their implied location in the estimated relationship. For a total of 172 countries with VAT taxation, the size of the dots reflects the number of countries having different current VAT rates. Small-sized dots indicate VAT rates present in 1 to 6 countries, medium-sized dots indicate VAT rates present in 7 to 11 countries, and large-sized dots indicate VAT rates present in 18 to 24 countries. The median and average VAT rate, 16 percent, is far from the VAT rate of 32 percent. While the minimum VAT rate is 5 percent, the maximum VAT rate is 27 percent (for only one country). In other words, no country in the world has a VAT rate above 32 percent, indicating that no country could reduce the VAT rate and still increase the corresponding revenue collection. In sum, while the Laffer curve is theoretically plausible in our framework, in practice no country is on the "wrong" side of the Laffer curve.

This evidence suggests that countries like, for example, Nigeria, with "excessive" dependency on commodity fiscal revenues could quickly mobilize revenues from non-commodity related activities by increasing their VAT rates with relatively little effect on economic activity.

\section{Concluding remarks}

Based on our paper titled "Non-linear effects of tax changes on output: The role of the initial level of taxation," this companion paper discusses some relevant policy implications. We first focused on the relevance of our arguments for revenue mobilization in countries with low levels of provision of public goods and social and infrastructure gaps (measured as deviations from the predicted value based on Wagner's law). Since such countries have typically low initial tax rates, we concluded that they could increase the VAT rate, and thus tax collection, at little or no cost and thus raise productive government spending.

We then focused on commodity-dependent countries and showed that countries with "excessive" dependence on commodity revenues tend to have a relative low VAT rate or none at 
all. Hence, as in the previous case, these countries could increase the VAT tax rate at little or not cost and thus reduce their dependency on commodity revenues. Thirdly, we explored some practical implications of our empirical findings for debt sustainability analysis. In particular, we showed that, when initial VAT rates are high, a tax hike is much less effective in preventing a rise in public debt if account is taken of the negative effect of higher VAT rates on output. Finally, we showed the implications for the Laffer curve of the non-linear response of output to increases in VAT rates and concluded that no country in the world could actually reduce the VAT rate and still increase total revenues. 


\section{References}

[1] Alesina, A., and R. Wacziarg (1998). "Openness, country size and government," Journal of Public Economics, Vol. 69, Issue 3, pp. 305-321.

[2] Arizala, F., C. Castro, E. Cavallo, and A. Powell (2008). "Debt sustainability fan charts: Combining multivariate regression analysis and external forecasts," Draft Working Paper (IDB).

[3] Bird, R. (1971). "Wagner's 'law' of expanding state activity," Public Finance, Vol. 26, No. 1, pp. 1-26.

[4] Diaz-Alvarado, C., A. Izquierdo, and U. Panizza (2004). "Fiscal sustainability in emerging market countries with an application to Ecuador," Research Department Working Paper No. 511 (IDB).

[5] Easterly, W., and S. Rebelo (1993). "Fiscal policy and economic growth: An empirical investigation," Journal of Monetary Economics, Vol. 32, Issue 3, pp. 417-458.

[6] Fatas, A., and I. Mihov (2001). "Government size and automatic stabilizers: International and intranational evidence," Journal of International Economics, Vol. 55, Issue 1, pp. 3-28.

[7] Gunter, S., D. Riera-Crichton, C. Vegh, and G. Vuletin (2021). "Non-linear effects of tax changes on output: The role of the initial level of taxation," Journal of International Economics, forthcoming.

[8] Milesi-Ferretti, G., R. Perotti, and M. Rostagno (2002). "Electoral systems and public spending," The Quarterly Journal of Economics, Vol. 117, Issue 2, pp. 609-657.

[9] Musgrave, R. (1969). Fiscal systems (New Haven: Yale University Press).

[10] Peacock, A., and J. Wiseman (1967). The growth of public expenditure in the United Kingdom (London: Allen and Unwin).

[11] Persson, T., and G. Tabellini (1999). "The size and scope of government: Comparative politics with rational politicians," European Economic Review, Vol. 43, Issues 4-6, pp. 699-735. 
[12] Rodrik, D. (1998). "Why do more open economies have bigger governments?," Journal of Political Economy, Vol. 106, No. 5, pp. 997-1032.

[13] Romer, C., and D. Romer (2010). "The macroeconomic effects of tax changes: Estimates based on a new measure of fiscal shocks," American Economic Review, Vol. 100, No. 3, pp. $763-801$.

[14] Wagner, A. (1883). Finanzwissenschaft (Leipzig: C.F. Winter).

[15] Wagner, A. (1893). Grundlegung der politischen oekonomie (Leipzig: C.F. Winter). 
Figure 1. Role of initial tax rate level and size of tax rate change

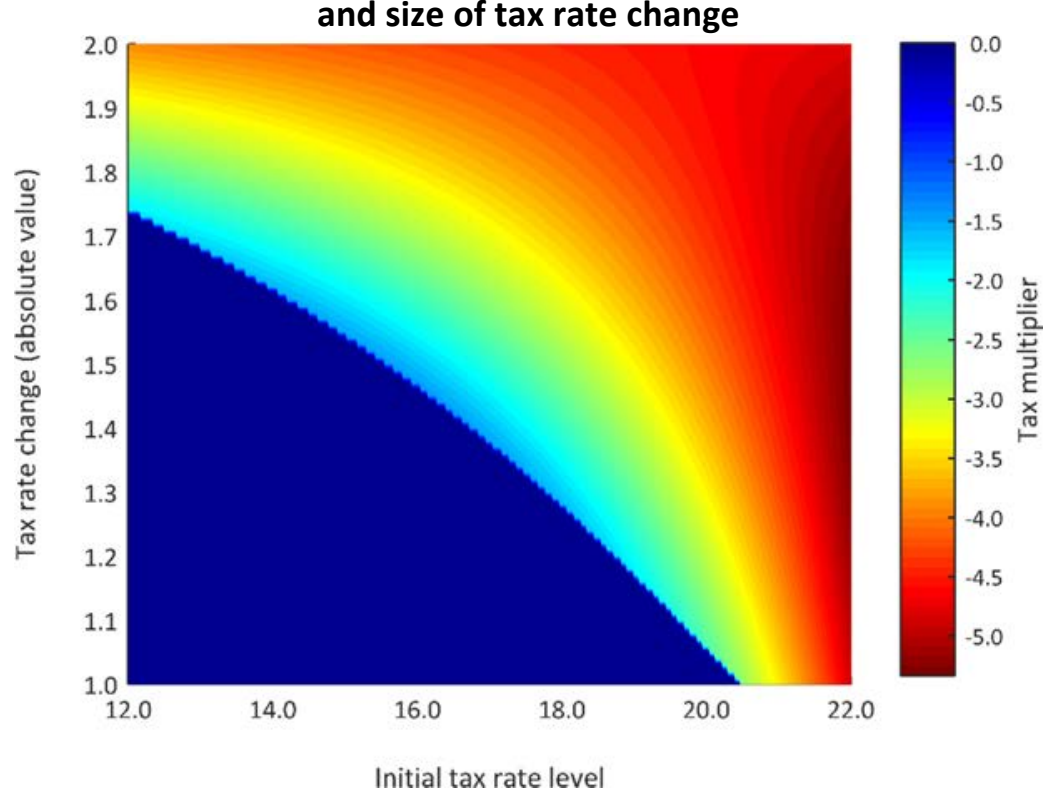

Notes: Dark blue represents a statistically zero tax multiplier. Source: Gunter, Riera-Crichton, Vegh, and Vuletin (2021).

Figure 2. Tax multipliers for countries around the world

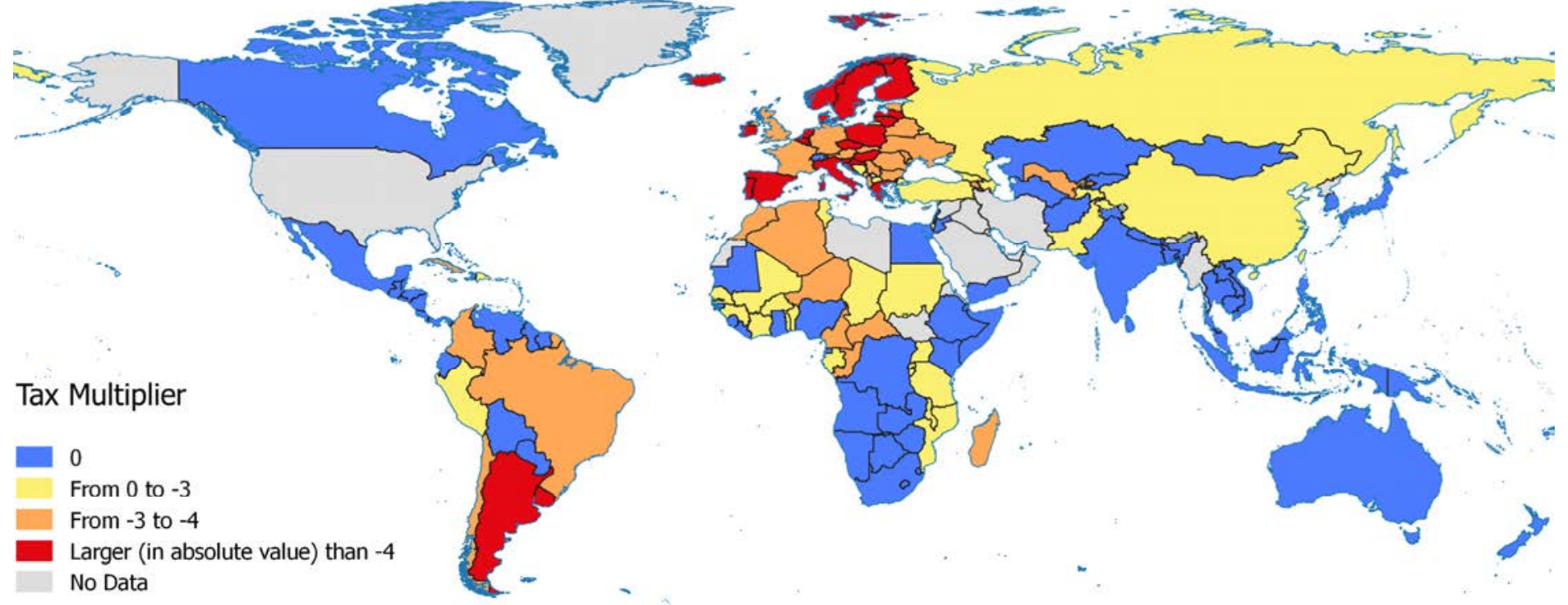

Notes: Tax multipliers are calculated based on a 1.5 percentage-points change in the VAT rate. Light blue indicates statistically zero tax multipliers. Source: Gunter, Riera-Crichton, Vegh, and Vuletin (2021). 
Figure 3. Relationship between GDP per capita and size of government spending relative to GDP

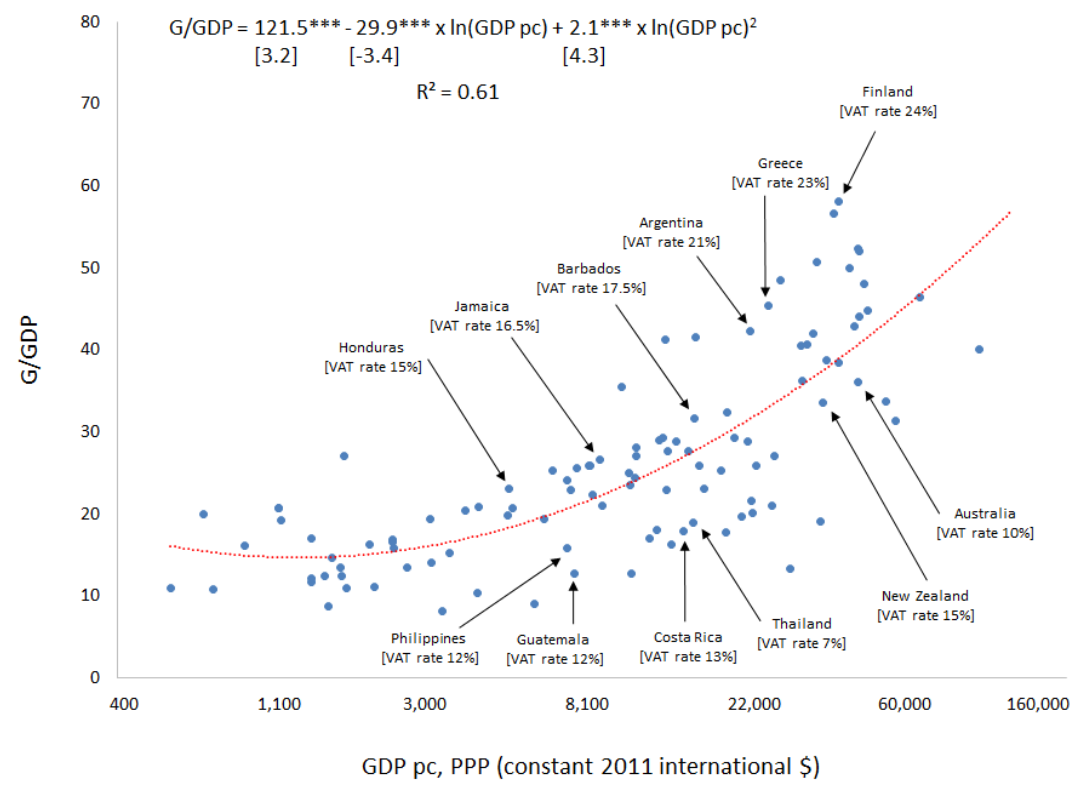

Notes: Data correspond to the year 2015. Total number of countries in the sample is 107 . Sources: Data for government spending over GDP ratio from WEO-IMF. Data for GDP per capita from World Penn Tables.

\section{Figure 4. Relationship between "excess" spending and VAT rate}

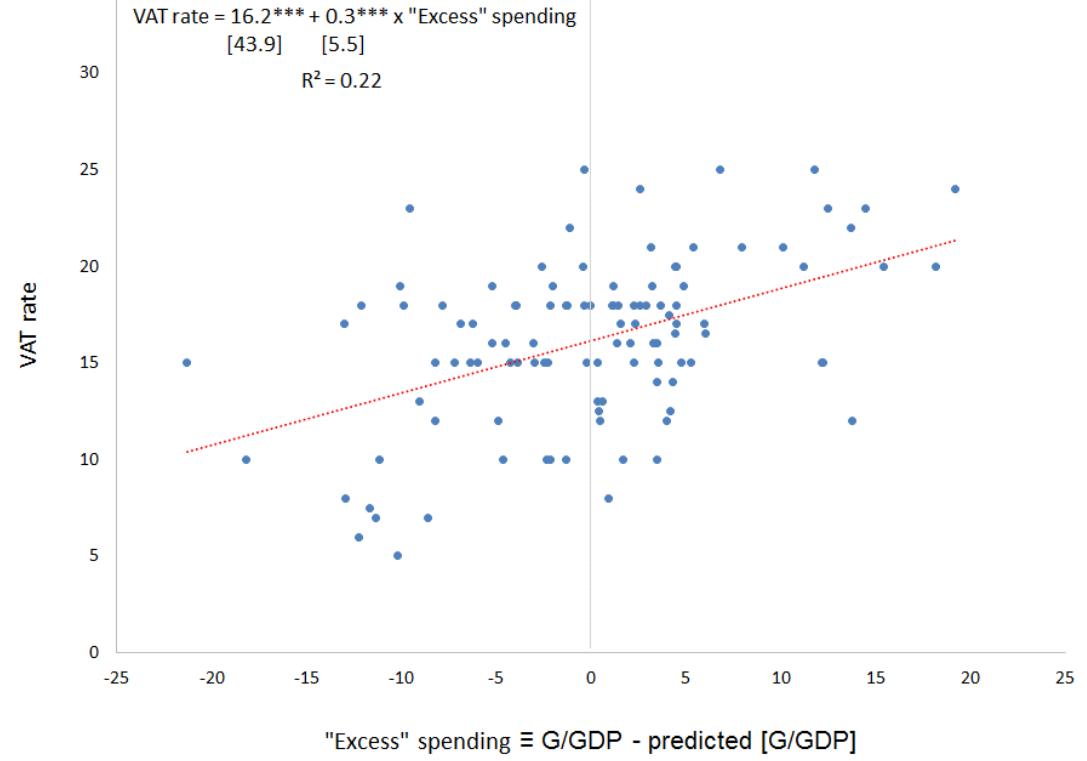

Notes: Data correspond to the year 2015. Total number of countries in the sample is 107. Sources: Data for government spending over GDP ratio from WEO-IMF. Data for GDP per capita from World Penn Tables. 


\section{Figure 5. Relationship between fiscal commodity revenues and price of commodities}

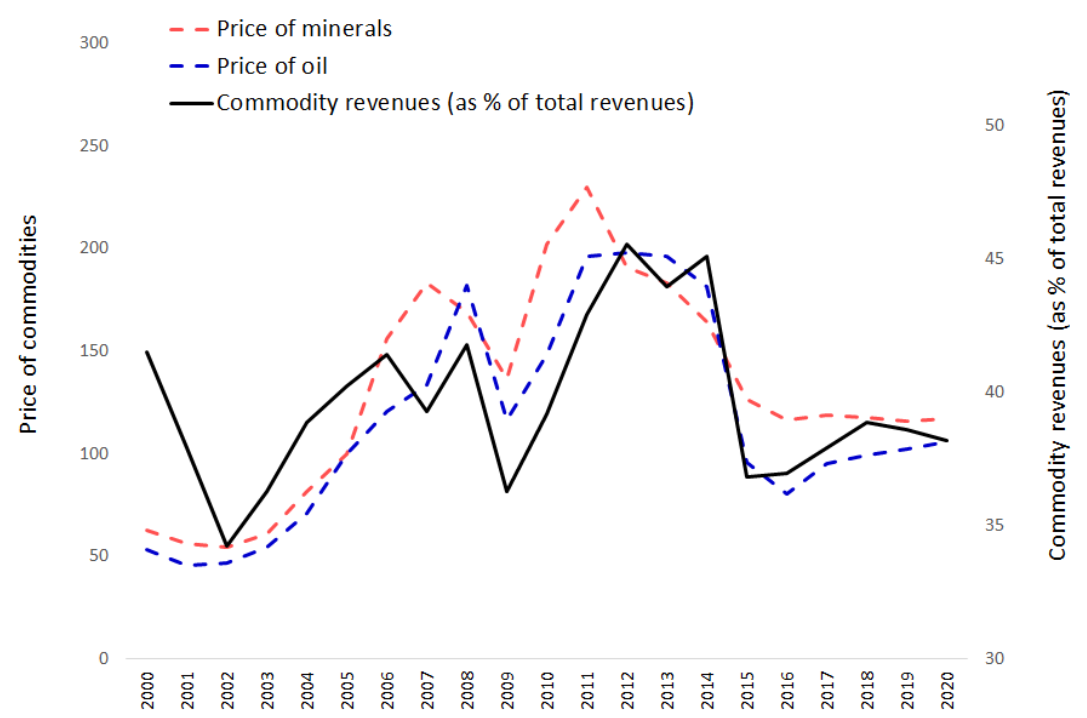

Notes: Total number of countries in the sample is 55 . Price of minerals includes copper, aluminum, iron, ore, tin, nickel, zinc, lead, and uranium prices indices. Price of oil is the simple average of three spot prices (Dated Brent, West Texas Intermediate, and the Dubai Fateh. Sources: Data for commodity revenues (as \% of total revenues) based on authors' computations using IMF and IDB information. Price of minerals and oil from IMF, PMETA, and POILAPSP.

Figure 6. Relationship between commodity GDP (as \% of GDP) and commodity revenues (as \% of total revenues)

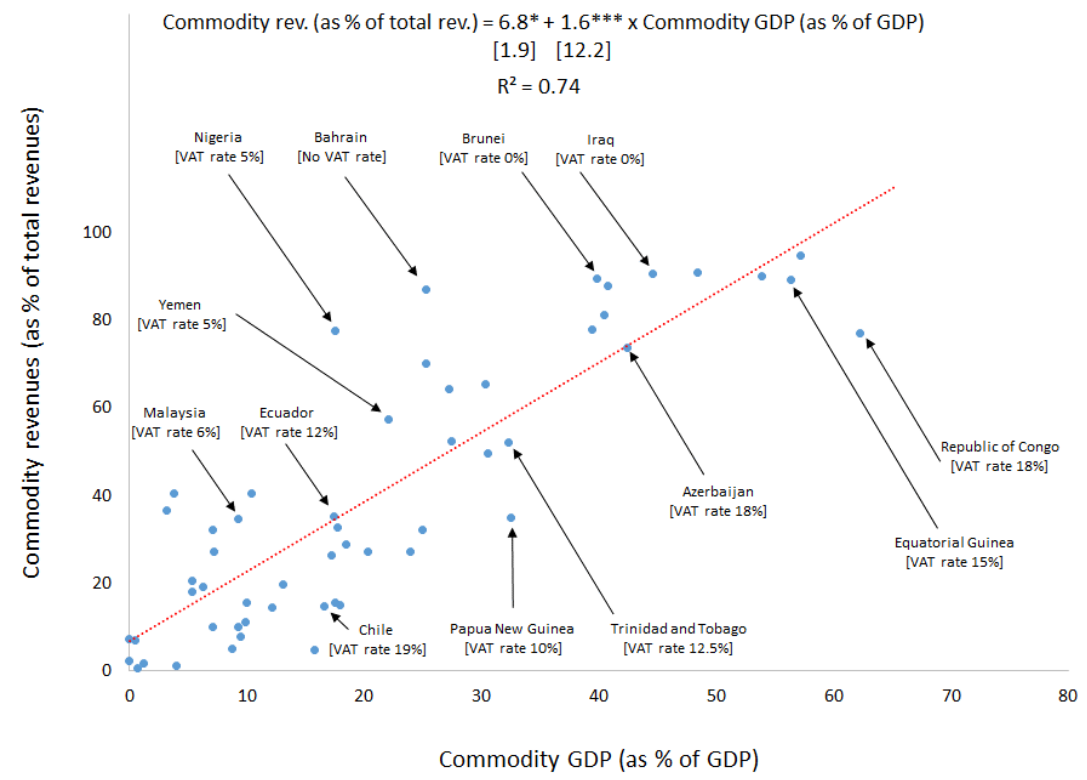

Notes: Data correspond to the period 2010-2013. Total number of countries in the sample is 55. Sources: Data for commodity revenues (as \% of total revenues) and commodity GDP (as \% of GDP) is based on authors' computations, using IMF and IDB information. 
Figure 7. Relationship between "excess" commodity revenue dependency and VAT rate

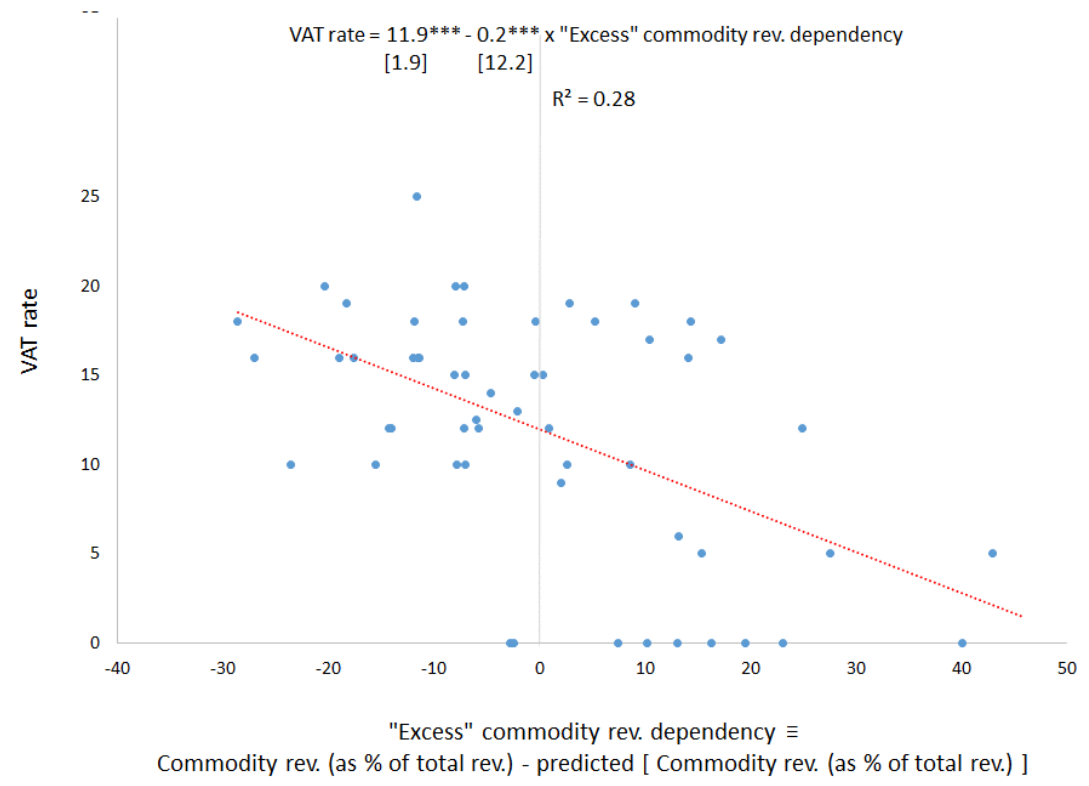

Notes: Data correspond to the period 2010-2013. Total number of countries in the sample is 55 . Sources: Data for commodity revenues (as \% of total revenues) and commodity GDP (as \% of GDP) based on authors' computations, using IMF and IDB information.

Figure 8. Change in debt to GDP ratio and cumulative output change under different model assumptions (two years after the tax shock)

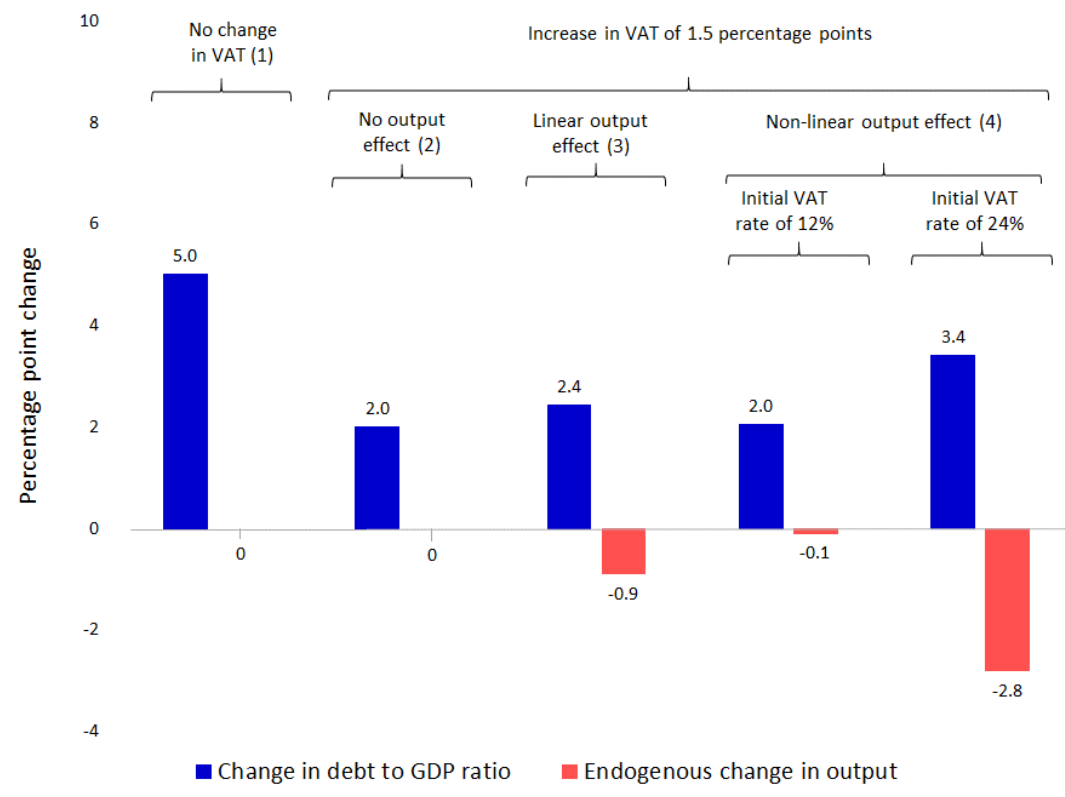

Source: Authors' computations. 
Figure 9. Relation between initial VAT rate and change in revenues as percentage of GDP in response to an increase in VAT rate of 1.5 percentage-points

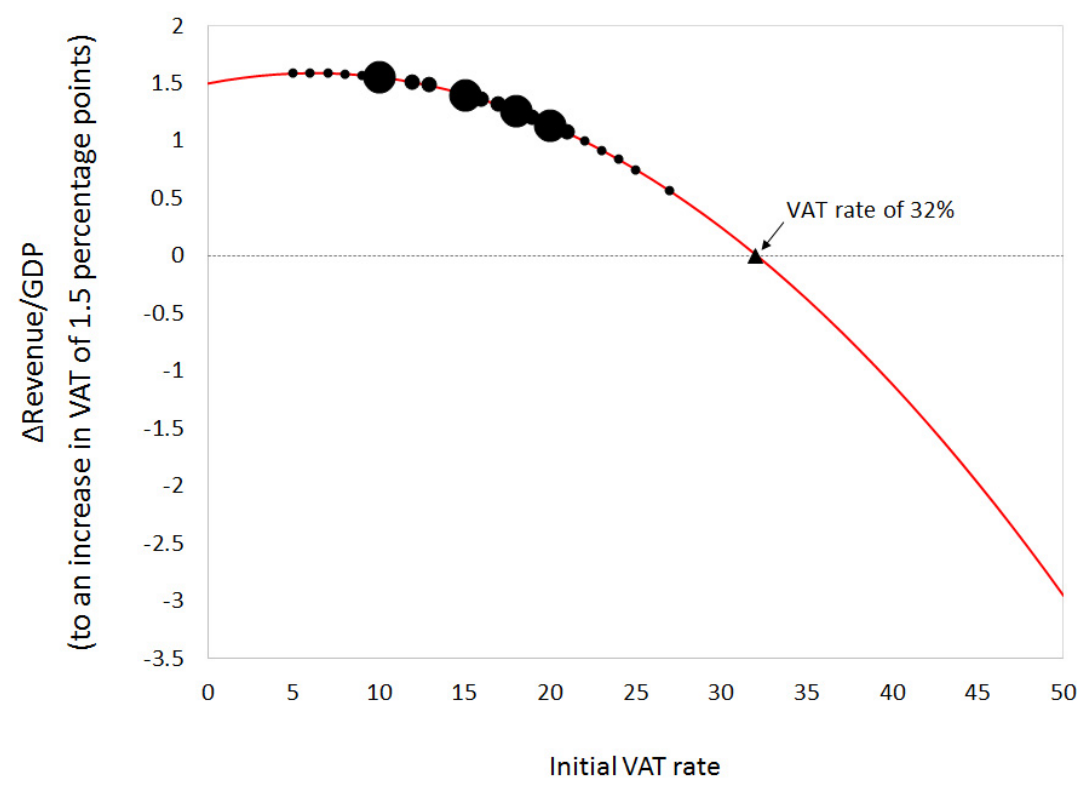

Notes: The solid red line indicates the change in revenues (as percentage of GDP) in response to a 1.5 percentage-point increase in the VAT rate, taking into account the non-linear findings and assuming (without loss of generality) that revenues are given by the VAT rate times GDP. Dotted points reflect number of countries with different VAT rates (as of November 2017). Source: Authors' computations. 